\title{
Oxidative DNA Damage Due to Occupational Exposure to Polycyclic Aromatic Hydrocarbons among Coal Tar Workers \\ BY
}

\author{
Shehata RA ${ }^{1}$, Helal SF ${ }^{1}$, Rashed $\mathbf{L A}^{\mathbf{2}}$ and Rakha AM ${ }^{\mathbf{1}}$ \\ ${ }^{1}$ Department of Occupational and Environmental Medicine, ${ }^{2}$ Department of \\ Biochemistry, Faculty of Medicine, Cairo University.
}

Corresponding author: Shehata RA: rehab.shehata@kasralainy.edu.eg

\section{Abstract}

Introduction: Polycyclic Aromatic hydrocarbons (PAHs) are compounds of occupational and environmental concern as they are toxic, carcinogenic, mutagenic, and/or teratogenic (causing birth defects). Occupational exposure during coal tar distillation process may cause numerous symptoms and diseases through generation of coal tar fumes that contain principally polycyclic aromatic hydrocarbons (PAHs). Benzopyrene is the most important member of those PAHs. Aim of work: To assess the health effect due to occupational exposure to PAHs; specifically their effects on DNA damage and oxidative stress status among coal tar workers. Materials and methods: A comparative cross sectional study was carried out on two groups, exposed and unexposed group. The exposed group was consisted of 40 coal tar workers and the unexposed group was also composed of 40 matched individuals not occupationally exposed to coal tar .All examined individuals were subjected to full occupational history and estimation of 1-hydroxypyrene (1-OHPyrene) level in urine, blood levels of Benzopyrene-DNA adducts, oxidative stress enzymes (superoxide dismutase and glutathione peroxidase), Cytochrome P450 and Complete blood picture. Results: There was a statistically significant higher urinary level of 1-OHPyrene and higher blood levels of benzopyrene DNA adducts at the exposed workers compared to unexposed ones, in the other hand there were significant reduction in serum levels of superoxide dismutase and glutathione peroxidase among workers exposed to PAHs compared to the unexposed group that might be consumed by oxidative stress status. Conclusion: Oxidative stress and DNA damage might be one of the pathogenesis that may cause adverse health effects associated with occupational exposure to PAHs among coal tar workers.

Keywords: Coal tar production, Polycyclic aromatic hydrocarbons, 1-Hydroxypyrene, DNA adducts and Oxidative stress enzymes. 


\section{Introduction}

Polycyclic aromatic hydrocarbons (PAHs) are a group of chemical compounds that is formed whenever anything with a carbon base is burned, from wood and gasoline to cigarettes and meat. PAHs are also in automobile tires and coal tar production which involves heating of carbon-based materials. PAHs are of environmental concern because they are toxic, mutagenic, teratogenic (causing birth defects) and harmful to aquatic life, and even they are probable human carcinogens (Abdel-Shafy and Mansour, 2016).

Studies of coke-oven pitch detected that coal tar pitch contained aromatic hydrocarbon ring systems including benzo[a]pyrene (BaP) and benzo[e] pyrene, benzofluoranthenes, perylene and heterocyclic compounds. Several studies showed evidence of carcinogenicity in human from occupational exposures during paving and roofing with coal tar pitch (Betts, 2000).

Benzo[a]pyrene $(\mathrm{BaP})$ is one of the most toxic components of the PAHs. $\mathrm{BaP}$ rarely exists in the air on its own but rather is associated with a large number of other PAHs present in both vapour phase or as particles. In some regulatory settings, $\mathrm{BaP}$ is used as an indicator for this group of chemically diverse air pollutants ( Alexandrov et al.,2010).
Individual PAHs such as benzo[a] pyrene and mixtures containing various PAHs have been determined to be carcinogenic to humans and animals. The route of exposure can influence the site of tumour induction although tumours can be present in other locations such as lung cancers after dermal exposures (CRCE, 2008).

Benzo[a]pyrene and other polycyclic aromatic hydrocarbons (PAHs) execute their carcinogenicity via formation of benzopyrene DNA adducts. Quantitation of DNA adducts in human tissues has been achieved with highly sensitive techniques based on adduct radio-labelling, antisera specific for DNA adducts. Studies were used to correlate DNA adducts with cancer risk, and elucidation of opportunities to reduce human DNA adduct levels formation (Poirier, 2004).

Benzopyerene DNA adduct was observed in different cell types. The levels were similar in various cell types; that suggested that DNA in many human tissues is continuously damaged from known exposure of humans to $\mathrm{BaP}$ and other PAH. Moreover, DNA adducts formed from $\mathrm{BaP}$ are persistent in lung and brain specifically (Boysen and Hecht, 2003). 
Free radicals and reactive oxygen species (ROS) that are generated during metabolism of polycyclic aromatic hydrocarbons (PAHs) can cause severe damage to cellular macromolecules (e.g. DNA, proteins, and lipids) via oxidative stress which have been reported to be involved in the development of diseases including cardiovascular, diabetes, and cancers for adult and birth defects for fetus (Patri et al., 2010).

Biochemical estimation of radical scavenging antioxidant enzymes, like superoxide dismutase and glutathione peroxidase, gives information on the possible imbalance between oxidant and antioxidant systems resulting on oxidative stress status responsible for the developing DNA damage and carcinogenic mechanism (Risom et al., 2005).

\section{Aim of the work}

The aim of this work is to assess the health effects due to occupational exposure to PAHs; specifically their effects on DNA damage and oxidative stress status among coal tar workers.

\section{Materials and methods}

Study design: Comparative cross sectional study.

Place and duration of the study: The study was conducted at section of coal tar distillation of coal manufacture at Helwan district, from October 2015 to June 2016.
Study sample: The studied population included 80 subjects divided into 40 exposed and 40 unexposed male workers. The exposed workers were taken from the section of coal tar distillation of coal manufacture at Helwan district, with duration of employment from 5 to 35 years. These workers were occupationally exposed to dust and fumes produced during coal tar distillation at 8 hours day shift for 5 days/week, the place is poorly ventilated or illuminated with lack of good housing. The other 40 unexposed males were selected from the outpatient clinics in Kasr Al-Ainy hospital with no history of occupational exposure to coal tar dust or fumes. Both groups were matched in age, sex, smoking and socioeconomic standard with the exposed group. Inclusion criteria: male workers exposed to polyaromatic hydrocarbons in their occupation for more than 5 years. Exclusion criteria involved cases with history of any type of cancer and moderate to heavy smokers (Smoking Index=20- 40 packlyear) (as tobacco smoke is a major source of human exposure to polycyclic aromatic hydrocarbons (PAHs) and increase cancer risk( Yan et al., 2006). Also presence of cancer have been reported to be associated by oxidative damage to biological molecules including DNA at adults (Patri et al., 2010)). So smoking or cancer might affect the results of the investigations of the present study. 


\section{Study Methods:}

The studied groups were subjected to the following:

I- Questionnaire: Specially designed questionnaire was used included: medical, present, past and family histories with emphasis on general toxic and respiratory manifestations.

\section{II-Clinical examination for:}

- Vital signs: pulse, blood pressure, respiratory rate and temperature.

- Skin examination: redness, dryness, cracks, itching marks and blisters.

- Chest examination: breath sounds, wheezes and crepitations.

\section{III-Laboratory investigations:}

1) Collection of blood samples About $10 \mathrm{ml}$ of venous blood was collected once from each individual in the examined groups using $\mathrm{K}_{2}$ EDTA plastic tubes.

\section{Sampling process:}

a) Antioxidant (Superoxide enzyme dismutase assays Glutathione peroxidase)

A total of $1.5 \mathrm{ml}$ of the total blood collected was processed to obtain serum for biochemical analysis. Protein determination was done in all samples (Rekhadevi et al., 2009).

\section{Superoxide}

(SOD) activity was measured spectrophotometrically.

xanthine-xanthine oxidase was utilized to generate a superoxide flux. Reduction of nitrobluetetrazolium (NBT) by superoxide anion to blue formazon was determined at 560 $\mathrm{nm}$. One unit of enzyme activity was defined as the amount of protein causing $50 \%$ inhibition in NBT reduction by superoxide (Rekhadevi et al., 2009).

Glutathione peroxidase (GPx) activity in serum was measured spectrophotometrically. The enzyme reaction was initiated by the addition of hydrogen peroxide $\left(\mathrm{H}_{2} \mathrm{O}_{2}\right)$ to the reaction medium and the rate of nicotinamide adenine dinucleotide phosphate (NADPH) oxidation was followed at $340 \mathrm{~nm}$. The amount of enzyme that oxidizes $1 \mu \mathrm{mol} \mathrm{NADPH}$ per minute was considered to be one unit (Rekhadevi et al., 2009).

Cytochrome P450 (CYP450) in serum activity was measured using ELISA method. This assay employs the quantitative sandwich enzyme immunoassay technique. Antibody specific for Cytochrome P450 has been pre-coated onto a microplate. Standards and samples are pipetted into the wells and any Cytochrome $\mathrm{P} 450$ present is 
bound by the immobilized antibody. After removing any unbound substances, a biotin-conjugated antibody specific for Cytochrome P450 is added to the wells. After washing, avidin conjugated Horseradish Peroxidase (HRP) is added to the wells. Following a wash to remove any unbound avidin-enzyme reagent, a substrate solution is added to the wells and color develops in proportion to the amount of Cytochrome P450 bound in the initial step. The color development is stopped and the intensity of the color is measured (Guengerich et al., 2009).

\section{b) Benzopyrene DNA adducts assessment:}

$5 \mathrm{ml}$ of the sample was used to measure Benzopyrene DNA adduct which was measured by ELISA kit supplied from Cell Biolabs. Inc.

\section{Principle of assay:}

Benzopyrene-DNA standards or unknown DNA samples are adsorbed onto a 96-well DNA high-binding plate. The benzopyrene-DNA adducts present in the sample or standard are probed with an Anti-benzopyrene antibody followed by HRP Conjugated Secondary Antibody. The benzopyreneDNA adduct content in an unknown sample is determined by comparing with a standard curve that is prepared from predetermined benzopyrene-DNA standards.
2) Collection of urine samples: Urine samples were collected post-shift (after 8 hours of work) from all examined group, in sterile $120 \mathrm{ml}$ urine collection cups then they were aliquoted into $15 \mathrm{ml}$ polypropylene tubes. Specimens were stored at $-20^{\circ} \mathrm{C}$ until analysis (Jongeneelen, 2001).

\section{a. Urine analysis for \\ 1-hydroxypyrene (1-OHP)}

The level of 1-OHP in the urine was determined using reverse-phase high performance liquid chromatography (HPLC) followed by their solid phase extraction. Ten milliliters of thawed urine was adjusted to $\mathrm{pH}$ 5.0, buffered with 10 $\mathrm{ml}$ of $0.1 \mathrm{M}$ sodium acetate buffer $(\mathrm{pH}$ 5.0 ), and enzymatically deconjugated by $25 \mu 1$ of $\beta$-glucuronidase/sulfatase (127300 units/ml and 7500 units $/ \mathrm{ml}$ ). After incubation overnight at $37^{\circ} \mathrm{C}$ in a shaker, the urine sample was centrifuged to extract the PAH metabolites using a LC-18 cartridge. After priming the cartridge with $2 \mathrm{ml}$ methanol, followed by $5 \mathrm{ml}$ of distilled water, the sample supernatant was passed through the cartridge at a rate of $5 \mathrm{ml} / \mathrm{min}$. The cartridge was then washed with $6 \mathrm{ml}$ of $0.1 \mathrm{M}$ sodium acetate buffer. 
The retained solutes were eluted with $1.5 \mathrm{ml}$ of isopropanol. The elute was evaporated at $45^{\circ} \mathrm{C}$ under nitrogen. The residue was then dissolved in $1.0 \mathrm{ml}$ of isopropanol. 1-OHP was quantitatively determined using HPLC equipped with a fluorescence detector with excitation and emission wavelengths of 241 and $388 \mathrm{~nm}$, respectively. A $25 \mu \mathrm{l}$ portion of each sample was injected to an Octadecylsilane (ODS) C18, $250 \times 4.6 \mathrm{~mm}$ column. 1-OHP concentrations were adjusted as micromole per milligram creatinine ( $\mu \mathrm{mol} /$ mg creatinine) ( Strickland and Kang, 1999).

\section{b. Urine analysis for creatinine}

A polypropylene tube containing 5 $\mathrm{ml}$ frozen urine was used for creatinine analysis. The creatinine level in the urine sample was measured with a Shimadzu model UV-1601 spectrophotometer using the Jaffé reaction (Kim et al., 2004).

\section{Consent}

Verbal consent was taken from all the workers who participated in the study and consent was taken from the management of the factory where the study was carried out and confidentiality was maintained.

\section{Ethical approval}

The study procedures were approved by the Occupational and Environmental Medicine Department Ethical Committee, Faculty of Medicine, Cairo University.

\section{Data management}

All statistical calculations were done using SPSS version 22 (Statistical Package for the Social Science; SPSS Inc., Chicago, IL, USA) for Microsoft Windows. Data were statistically described in terms of arithmetic Mean \pm Standard deviation $(\mathrm{X} \pm \mathrm{SD})$ and range, frequencies (number of cases) and percentages.

Multivariate analysis was performed using logistic regression modeling with the outcomes of various qualitative parameters. Variables included in the final multivariate models were chosen on the basis of biologic plausibility of their association with the outcomes, in addition to the statistical and epidemiological criteria. Statistical significance was considered using $\mathrm{p}$ values less than 0.05 . 


\section{Results}

Table (1): The mean values, ranges and standard deviation of biochemical investigations among the studied groups.

\begin{tabular}{|c|c|c|c|c|c|c|}
\hline \multirow[t]{2}{*}{ Parameters } & \multicolumn{2}{|c|}{$\begin{array}{l}\text { Exposed } \\
\text { (No:40) }\end{array}$} & \multicolumn{2}{|c|}{$\begin{array}{c}\text { Non- Exposed } \\
\text { (No:40) }\end{array}$} & \multicolumn{2}{|c|}{ Statistical significance } \\
\hline & Mean & + SD & Mean & + SD & t test & p value \\
\hline $\begin{array}{l}\text { One hydroxypyrene } \\
(1-\mathrm{OH}-\mathrm{P})(\mathrm{ng} / \mathrm{mg} \\
\text { creatinine) }\end{array}$ & 7.96 & \pm 3.51 & 0.14 & \pm 0.08 & 14.06 & $<0.0001 * *$ \\
\hline $\begin{array}{l}\text { DNA adduct } \\
\text { (adducts } / 10^{\wedge} 8 \mathrm{nt} \text { ) }\end{array}$ & 3.21 & \pm 2.86 & 0.28 & \pm 0.23 & 6.46 & $<0.0001 * *$ \\
\hline $\begin{array}{l}\text { SOD (Super Oxide } \\
\text { Dismutase) }\end{array}$ & 1.01 & \pm 0.63 & 2.62 & \pm 0.80 & -9.99 & $<0.0001 * *$ \\
\hline $\begin{array}{l}\text { GPx (Glutathione } \\
\text { Peroxidase) }\end{array}$ & 30.25 & \pm 13.44 & 57.23 & \pm 7.78 & -10.9898 & $<0.0001 * *$ \\
\hline $\begin{array}{l}\text { CYP } 450 \\
\text { (Cytochrome P450) }\end{array}$ & 6.43 & \pm 4.54 & 1.3 & \pm 0.46 & 7.11 & $<0.0001 * *$ \\
\hline
\end{tabular}

** Highly statistically significant

Table (1) demonstrated that there were statistically high significant differences between exposed and non-exposed groups as regards Hydroxypyrene level, antioxidant enzymes (SOD and GPx), Benzopyrene DNA adduct level and CY450 (P $<0.0001)$. 
Table (2): Frequency of health problems among the studied groups.

\begin{tabular}{|l|c|c|c|c|c|c|}
\hline \multirow{2}{*}{ Parameters } & \multicolumn{2}{|c|}{$\begin{array}{c}\text { Exposed } \\
\text { (No:40) }\end{array}$} & \multicolumn{2}{c|}{$\begin{array}{c}\text { Non- Exposed } \\
\text { (No:40) }\end{array}$} & \multicolumn{2}{|c|}{$\begin{array}{c}\text { Statistical } \\
\text { significance }\end{array}$} \\
\cline { 2 - 7 } & No & $\mathbf{\%}$ & No & \% & $\mathbf{X}^{\mathbf{2}}$ & p value \\
\hline $\begin{array}{l}\text { Chest Symptoms (Cough, } \\
\text { Dyspnea or Expectoration) }\end{array}$ & 18 & $45 \%$ & 9 & $23 \%$ & 7.17 & $<\mathbf{0 . 0 5 *}$ \\
\hline Diabetes & 3 & $8 \%$ & 2 & $5 \%$ & 3.1 & $>0.05$ \\
\hline Hypertension & 3 & $8 \%$ & 2 & $5 \%$ & 3.1 & $>0.05$ \\
\hline
\end{tabular}

* Statistically significant

Table (2) showed a statistically significant increase in chest symptoms among exposed workers (45\%) compared to non-exposed group (23\%), diabetes and hypertension were higher among the exposed group but not to a statistical level.

Table (3): Correlation between hydroxypyrene in urine and other oxidative parameters among the exposed groups.

SOD: (Super Oxide Dismutase) GP: (Glutathione Peroxidase) CYP 450: (Cytochrome P450)

* Statistically significant

** Highly statistically significant

Table (3) demonstrated that there was a statistically significant positive correlation between the Hydroxypyrene and DNA adduct. While, there was a statistically significant negative correlation between hydroxypyrene level in urine of the exposed group and antioxidant enzymes (SOD and GPx) and there was a statistically negative correlation between hydroxypyrene and CYP450 but it didn't reach significant level. 


\section{Table (4): Correlation between duration of exposure to PAH and} hydroxypyrene, other oxidative parameters among the exposed workers.

\begin{tabular}{|l|c|c|}
\hline Duration Vs & r & p value \\
\hline One hydroxypyrene (1-OH-P) (ng/mg creatinine) & 0.602 & $<\mathbf{0 . 0 0 1} 1^{* *}$ \\
\hline DNA adduct (adducts $\left./ 10^{\wedge} 8 \mathrm{nt}\right)$ & 0.409 & $<\mathbf{0 . 0 5}$ \\
\hline SOD & -0.448 & $<\mathbf{0 . 0 5}$ \\
\hline GPx & -0.686 & $<\mathbf{0 . 0 0 1} 1^{* *}$ \\
\hline CYP 450 & 0.22 & $>0.05$ \\
\hline
\end{tabular}

SOD: (Super Oxide Dismutase) GPx: (Glutathione Peroxidase)

CYP 450: (Cytochrome P450)

* Statistically significant

** Highly statistically significant

Table (4) showed that there was a statistically significant positive correlation between the duration of exposure to PAH and the levels of one hydroxypyrene, and DNA adduct. Also there was statistically significant negative correlation between the duration of exposure and anti-oxidant enzymes (SOD and GPx). There was a positive correlation between the duration of exposure to PAH and CYP 450 but it didn't reach significant level.

Table (5): Regression analysis between hydroxypyrene and other investigations in the exposed workers to PAH .

\begin{tabular}{|c|c|c|c|}
\hline \multirow{3}{*}{\begin{tabular}{l} 
Hydroxypyrene Vs \\
\multicolumn{1}{c}{ Beta } \\
Predictors \\
SOD GPx
\end{tabular}} & $\begin{array}{c}\text { Standardized } \\
\text { Coefficients }\end{array}$ & \multirow{2}{*}{$\begin{array}{c}\mathbf{t} \\
0 \\
0.020\end{array}$} & \multirow{3}{*}{$\begin{array}{c}\text { Sig. } \\
>0 . \\
05 \\
<0.001 * *\end{array}$} \\
\hline & & & \\
\hline & -0.649 & -4.415 & \\
\hline DNA adduct & 0.722 & 6.43 & $<0.001 * *$ \\
\hline CYP 450 & -0.029 & -0.235 & $>0.05$ \\
\hline
\end{tabular}

Table (5) used regression analysis with hydroxypyrene levels which was a dependent variable in the model while DNA adduct, SOD, GPx and CYP450 entered the model as independent variables. Table 5 showed that GPx and benzopyerene DNA adducts levels were statistically significant predictors to hydroxypyrene levels while SOD and CYP 450 were statistically insignificant predictors to hydroxypyrene. 


\section{Discussion}

Polycyclic aromatic hydrocarbons are group of several hundred chemicallyrelated environmentally persistent organic compounds with benzopyrene as one of their most prominent member. Oxidative stress is caused by imbalance between oxidants and antioxidants in favor of oxidants ( Birben et al.,2012.

The benzopyrene DNA adducts can be used to detect the exposure effect of benzopyrene (Boström et al., 2002).

As regard biochemical parameters; the current study revealed a highly statistically significant difference between exposed and non-exposed groups as regards Hydroxypyrene levels in urine, anti-oxidant enzymes (SOD and GPx), Benzopyrene DNA adduct level and CY450 as shown in (Table 1). This agreed with the study done by Jongeneelen in (2001) which showed that 1-hydroxypyrene urine level was higher among workers exposed to PAHs in coal tar distillation industry and he suggested in his study that using the concentration of 1-hydroxypyrene in urine, collected at the end of a working week, can be used as a biological indicator of recent exposure to PAH.
The high levels of benzopyrene DNA adducts among exposed workers at the present study was similar to the work done by Pratt and his colleagues, in (2011) on polycyclic aromatic hydrocarbon (PAH) exposure and DNA Adduct semi-quantitation in archived human tissues ; who stated that PAH exposures result in PAH-DNA adduct formation simultaneously in many tissues of the body. They are also close to the study done by Godschalk and his team in (2000) who showed that PAHs are thought to elicit cancer cells via formation of DNA adducts .

In the present study, the prevalence of respiratory symptoms was significantly higher among the exposed group compared to non-exposed one (Odds Ratio=2.8) .Among exposed workers $45 \%$ suffered from respiratory symptoms; dyspnea (60\%), cough with expectoration (17.5\%) and wheezy chest $(12.5 \%)$ (Table 2) . This could be attributed to the fact that chronic exposure to different effluents during coal tar distillation process can be associated with higher probability of chronic bronchitis ( Hu et al., 2006). In accordance to our results, Greenberg ( 2003) in his study on occupational, industrial, and environmental toxicology; revealed that coal tar 
products can be irritating and might cause both upper and lower respiratory symptoms and workers exposed to coal tar products especially roofers are highly susceptible to irritation of the respiratory tract leading to cough, sneezing, dyspnea and wheezes .

The results of the present work showed that there were statistically significant negative correlations between hydroxypyrene level in urine of examined groups and each of SOD, GPx and CYP450. While, there was a statistically significant positive correlation between the hydroxypyrene and DNA adduct as shown in table (3). These were consistent with what was detected by Dong and his team in (2000) that 1-hydroxypyrene causes DNA single-strand cleavages and forms Hydroxypyrene-DNA covalent adducts. Also confirmed by other studies as those done by Lewtas in (2007) which demonstrated that exposure to PAH may induce dosedependently elevated levels of aromatic DNA adducts in mononuclear cells and of 1-hydroxypyrene in urine, indicating substantial bioactivation of PAH.

The results of the current work ( Table 3) were in accordance with the study done by Xie and his coworkers
( 2015) on the effects of a fruitvegetable dietary pattern on oxidative stress and genetic damage in coke oven workers: a cross-sectional study; who found that exposure to PAHswas significantly related to higher urinary 1-hydroxypyrene levels andlower antioxidant levels [superoxidedismutase (SOD) and glutathioneperoxidase, (GPx)].

The present work showed that there were statistically significant negative correlations between the duration of exposure to $\mathrm{PAH}$ and anti-oxidant enzymes (SOD and GPx). Also there were positive correlations between the duration of exposure to $\mathrm{PAH}$ and the levels of CYP 450, DNA adduct and one hydroxypyrene which were nonsignificant with CYP450, significant with DNA adducts and highly significant with hydroxypyrene respectively as shown in (Table 4). McClean and his coworkers found in (2004) that pavement workers with high exposure to coal tar effluents and PAHs had high levels of urinary 1-hydroxypyrene that positively correlated with duration of exposure. Also Rojas and his colleagues has demonstrated in (2000) that levels of Benzopyrene-DNA adducts increased with duration of exposure to PAHs. Moreover, Rekhadevi and 
his co-workers in (2009) detected that age, smoking, alcohol consumption and duration of exposure to PAH or coal tar per day had a significant effect on DNA damage and DNA adduct formation. Finally, Xiong and his team in (2016) proved that long-term exposure to coal tar may reduce the antioxidant ability (decrease SOD) and increase the risk of DNA damage forming DNA adducts in refueling workers at gas stations.

The current study was conducted to explore the real dependency between levels of hydroxypyrene and DNA adducts formation and the effect of antioxidant enzymes levels among the exposed group only. Independent variables entered the model were SOD, GPX, CYP450 and benzopyrene DNA adducts with hydroxypyrene as dependent variables(Table 5). The model revealed that GPx and benzopyrene DNA adducts were highly significant predictors to one hydroxypyrene. Similar to our results, Akcha and his coworkers (2000) in their study on enzymatic biomarker measurement and study of DNA adduct formation in benzo [a] pyrene-contaminated mussels detected that one hydroxypyrene can be used as a biomarker to benzopyrene DNA adducts.
Therefore, in the current study we found that exposure to PAHs may cause a significant rise in hydroxypyrene levels in urine which was statistically significant associated with benzopyreneDNA adduct formation levels. DNA adduct is an early biological indicator of DNA damage in the exposed group while reduced antioxidant enzymes are biological indicators for oxidative stress occurred by high hydroxypyrene levels among coal workers.

\section{Conclusion and recommendations}

The exposure to coal tar causes several health hazards including DNA damage to the exposed workers, respiratory and oxidative stress. These health hazards occurred mainly due to the presence of PAHs toxic compounds generated during coal tar distillation process mainly benzopyrene.

Biological monitoring of exposure is a part of occupational health assessment as it aims at early detection and elimination of potential hazards at the work environment and at prioritizing areas of concern as using hydroxypyrene levels in urine as a biological index for exposure to polycyclic aromatic hydrocarbons. It was significantly higher among exposed groups and significantly correlated with longer duration of exposure. 
Strict precautions should be implemented to all workers exposed to PAH effluents including pre-employment and periodic medical examination which include clinical examination; determine levels for urinary hydroxypyrene level, DNA adducts and oxidative stress indicators as superoxide dismutase and glutathione peroxidase to asses exposure effect, regular environmental assessment is recommended according to OSHA and NIOSH exposure limits. Engineering controls should be supplemented with the use of isolated automated smelting machines keeping workers apart from exposures, also reducing or dividing work shift hours may reduce the exposure to harmful effects. Also health education is mandatory about hazardous health effects of exposure to PAH effluents and proper usage of personal protective measures like respirators with specific filters and face shields.

\section{Financial support}

None

\section{Conflict of interest}

There is no conflict of interest.

\section{References}

1. Abdel-Shafy HI and Mansour MS (2016): A review on polycyclic aromatic hydrocarbons: source, environmental impact, effect on human health and remediation. Egyptian Journal of Petroleum; 25: 107-23.

2. Akcha F, Izuel C, Venier P, Budzinski H, Burgeot T ,et al. (2000): Enzymatic biomarker measurement and study of DNA adduct formation in benzo [a] pyrene-contaminated mussels, Mytilus galloprovincialis .Aquat Toxicol; 49: 269-87.

3. Alexandrov K, Rojas M and Satarug S (2010): The critical DNA damage by benzo (a) pyrene in lung tissues of smokers and approaches to preventing its formation. Toxicol Lett ; 198: 63-8.

4. Betts W (2000): Tar and Pitch in KirkOthmer encyclopedia of chemical technology. New York: Wiley; 5: 1-20.

5. Birben E, Sahiner UM, Sackesen C, Erzurum S and Kalayci O (2012): Oxidative Stress and Antioxidant Defense. World Allergy Organ; 5: 9-19.

6. Boström CE, Gerde P, Hanberg A, Jernström B, Johansson C, et al. (2002): Cancer risk assessment, indicators, and guidelines for polycyclic aromatic hydrocarbons in the ambient air. Environ Health Perspect ; 110: 1-451. 
7. Boysen G and Hecht SS (2003): Analysis of DNA and protein adducts of benzo [a] pyrene in human tissues using structurespecific methods. Mutat Res; 543: 17-30.

8. CRCE (2008): The Centre for Radiation, Chemical \& Environmental Hazards: Polycycl Aromat Comp (Benzo[a] pyrene); 1: 1-24.

9. Dong S, Hwang H-M, Shi X, Holloway $\mathrm{L}$ and $\mathrm{Yu} \mathrm{H}$ (2000): UVA-Induced DNA Single-Strand Cleavage by 1-Hydroxypyrene and Formation of Covalent Adducts between DNA and 1-Hydroxypyrene. Chem Res Toxicol; 13: 585-93.

10. Godschalk RWL, Moonen EJC, Schilderman PAEL, Broekmans WMR, Kleinjans JCS, et al. (2000): Exposureroute-dependent DNA adduct formation by polycyclic aromatic hydrocarbons. Carcinogenesis; 21: 87-92.

11. Greenberg MI (2003): Occupational, industrial, and environmental toxicology. J Environ Sci Healt Elsevier; 340:1.

12. Guengerich FP, Martin MV, Sohl CD and Cheng Q (2009): Measurement of cytochrome $\mathrm{P} 450$ and NADPHcytochrome $\mathrm{P} 450$ reductase. Nature protocols; 4: 1-13.

13. Hu Y, Zhou Z, Xue X, Li X, Fu J, et al. (2006): Sensitive biomarker of polycyclic aromatic hydrocarbons (PAHs): urinary 1-hydroxyprene glucuronide in relation to smoking and low ambient levels of exposure. Biomarkers ; 11: 306-18.

14. Jongeneelen FJ (2001): Benchmark guideline for urinary 1-hydroxypyrene as biomarker of occupational exposure to polycyclic aromatic hydrocarbons. Ann Occup Hyg; 45: 3-13.

15. Jorgensen E (2010): Ecotoxicology, $1^{\text {st }}$ Edition. Academic Press, United States of America eBook ISBN: 9780444536297; 1: 319-23.

16. Kamal A, Cincinelli A, Martellini $T$ and Malik RN (2016): Biomarkers of PAH exposure and hematologic effects in subjects exposed to combustion emission during residential (and professional) cooking practices in Pakistan. Environ Sci Pollut R; 23: 1284-99.

17. Kim JY, Mukherjee S, Ngo LC and Christiani DC (2004): Urinary 8-hydroxy-2'-deoxyguanosine as a biomarker of oxidative DNA damage in workers exposed to fine particulates. Environ Health Perspect; 112: 666.

18. Lewtas J (2007): Air pollution combustion emissions: characterization of causative agents and mechanisms associated with cancer, reproductive, and cardiovascular effects. Mutation Research/Reviews in Mutat Res; 636: 95-133. 
19. McClean M, Rinehart R, Ngo L, Eisen E, Kelsey K, et al. (2004): Urinary

1-hydroxypyrene and polycyclic aromatic hydrocarbon exposure among asphalt paving workers. Ann Occup Hyg; 48: 565-78.

20. Patri M, Padmini A and Babu PP (2010): Polycyclic aromatic hydrocarbons in air and their neurotoxic potency in association with oxidative stress: a brief perspective. Ann Neurosci; 16: 22-30.

21. Poirier MC (2004): Chemical-induced DNA damage and human cancer risk. Nat Rev Cancer; 4: 630-7.

22. Pratt MM, John K, MacLean AB, Afework S, Phillips DH et al. (2011): Polycyclic Aromatic Hydrocarbon (PAH) Exposure and DNA Adduct SemiQuantitation in Archived Human Tissues. Int J Env Res Pub He; 8: 2675-91.

23. Rekhadevi PV, Mahboob M, Rahman MF and Grover P (2009): Genetic damage in wood dust-exposed workers. Mutagenesis; 24: 59-65.

24. Risom L, Moller P and Loft S (2005): Oxidative stress-induced DNA damage by particulate air pollution. Mutat Res; 592: 119-37.

25. Rojas M, Cascorbi I, Alexandrov K, Kriek E, Auburtin G, et al.: (2000): Modulation of benzo[a]pyrene diolepoxide-DNA adduct levels in human white blood cells by CYP1A1,
GSTM1 and GSTT1 polymorphism.

Carcinogenesis; 21: 35-41.

26. Strickland P and Kang D (1999): Urinary 1-hydroxypyrene and other PAH metabolites as biomarkers of exposure to environmental $\mathrm{PAH}$ in air particulate matter. Toxicol Lett; 108: 191-9.

27. Vene R, Castellani P, Delfino L, Lucibello M, Ciriolo MR, et al. (2011): The cystine/cysteine cycle and GSH are independent and crucial antioxidant systems in malignant melanoma cells and represent druggable targets. Antioxid Redox Signal ;15: 2439-53.

28. Xie Z, Lin H, Fang R, Shen W, Li S et al. (2015): Effects of a fruit-vegetable dietary pattern on oxidative stress and genetic damage in coke oven workers: a cross-sectional study. Environ; 14: 40.

29. Xiong F, Li Q, Zhou B, Huang J, Liang G, et al. (2016): Oxidative Stress and Genotoxicity of Long-Term Occupational Exposure to Low Levels of BTEX in Gas Station Workers. Int J Env Res Pub He; 13: 1212.

30. Yan SD, Xizheng JY, Ram BJ, Eugene L, Ameer T, et al. (2006): Determination of 14 Polycyclic Aromatic Hydrocarbons in Mainstream Smoke from U.S. Brand and Non-U.S. Brand Cigarettes. Environ Sci Technol; 404:1133-8. 
